\title{
ADSORPTION OF HEAVY METALS AND RESIDUAL OIL FROM PALM OIL MILL EFFLUENT USING A NOVEL ADSORBENT OF ALGINATE AND MANGROVE COMPOSITE BEADS COATED WITH CHITOSAN IN A PACKED BED COLUMN
}

\author{
RANA JAAFAR JAWAD*, MOHD HALIM SHAH ISMAIL \\ AND SHAMSUL IZHAR SIAJAM \\ Department of Chemical and Environmental Engineering, Faculty of Engineering, \\ Universiti Putra Malaysia, 43400 UPM Serdang, Selangor, Malaysia. \\ "Corresponding author: ranajaafarjawad@yahoo.com
}

(Received: 14 ${ }^{\text {th }}$ Sept 2016; Accepted: $5^{\text {th }}$ May 2017; Published on-line: $1^{\text {st }}$ June 2018)

https://doi.org/10.31436/iiumej.v19i1.734

\begin{abstract}
In this study, a novel adsorbent was prepared, namely alginate and mangrove composite beads coated with chitosan (AMCBCC), and performed well to remove heavy metals and residual oil from palm oil mill effluent (POME) using continuous adsorption studies in a fixed bed column under different bed heights. Thomas and Yoon-Nelson models were applied to predict the breakthrough curve and to compute the characteristic parameters such as maximum capacity and the time required for $50 \%$ of adsorbate breakthrough. It was found that the total removal percentage of iron ions, zinc ions, and residual oil were $26.75 \%, 76.74 \%$, and $83 \%$ respectively at $\mathrm{pH} 3$, and a bed height $27 \mathrm{~cm}$. Both models can well describe the breakthrough curve of heavy metals and residual oil. These results indicated that AMCBCC can be used to remove heavy metals and residual oil from industrial wastewater.
\end{abstract}

ABSTRAK: Kajian ini menyediakan tentang penjerap baharu iaitu alginat dan manik komposit bakau bersalut kitosan (AMCBCC), berfungsi menyingkirkan logam berat dan sisa minyak daripada efluen kilang minyak sawit (POME) dengan sempurna, menggunakan kajian penjerapan berterusan dalam lapisan lajur tetap pada ketinggian berbeza. Model Thomas dan Yoon-Nelson telah digunakan bagi meramal lengkungan terbaik dan mengira parameter cirian seperti keupayaan maksimum dan tempoh diperlukan bagi 50\% lengkungan terbaik penjerap. Jumlah peratusan penyingkiran ion besi, ion zink, dan sisa minyak masing-masing sebanyak $26.75 \%, 76.74 \%$, dan $83 \%$ pada $\mathrm{pH} 3$, dan pada ketinggian lapisan $27 \mathrm{~cm}$. Kedua-dua model mampu menggambarkan lengkungan terbaik bagi logam berat dan sisa minyak dengan sempurna. Dapatan ini menunjukkan AMCBCC sesuai digunakan bagi menyingkirkan logam berat dan sisa minyak daripada air sisa industri.

KEYWORDS: continuous adsorption; heavy metals; residual oil; palm oil mill effluent; adsorbent 


\section{INTRODUCTION}

The palm oil industry is considered to be a major industry and a key contributor to economic prosperity in Malaysia. A huge amount of effluent is discharged during the palm oil production process, which is known as palm oil mill effluent (POME).

POME is a thick brown liquid owing to the presence of lignin, humic acid, lipids, fatty acids, and tannin [1]. It is hot with a temperature between $80{ }^{\circ} \mathrm{C}$ and $90{ }^{\circ} \mathrm{C}$ and acidic with a $\mathrm{pH}$ of $4.5-5$ [2]. POME is oily wastewater mainly consisting of the following: water $95 \%$ - 96\%, total solid 4\% - 5\%, and oil and Grease $0.6 \%$ - 0.7\% [3]. The presence of residual oil in POME can pollute water sources and cause harmful effects to all aquatic creatures if it is discharged without treatment because POME has the ability to form an oily layer on the water surface. This reduces the light penetration into the water and subsequently has an adverse effect on photosynthesis. Moreover, this oily layer decreases the transfer of oxygen from air to water, leading to a low level of dissolved oxygen in water. This creates a direct threat to marine living organisms, which in turn leads to adverse effects on humans through the food chain [4]. The residual oil content in untreated POME is is very high, at an average of $9065 \mathrm{mg} / \mathrm{l}$ [5], which exceeds the permissible limits issued by the Department of Environmental (DOE) Malaysia (50 mg/l). Moreover, POME contains many heavy metals in critical levels such as iron and zinc. Iron ions have the highest concentration and are found at a dangerous levels in POME with an average of $119.5 \mathrm{mg} / \mathrm{l} \mathrm{[6],} \mathrm{which} \mathrm{exceeds} \mathrm{the}$ permissible limits $(5 \mathrm{mg} / \mathrm{L})$ issued by DOE Malaysia. Heavy metals are non-biodegradable, toxic, and bio-accumulate in aquatic living organisms. They can also be transferred to humans through the food chain, and can cause many diseases such as cancer [7-8]. Untreated POME causes severe water and soil pollution. It changes the water to brown, stinky, and slimy, which may eliminate living marine organisms and also endanger the planet in the case of discharging POME on land [9-10]. Although various methods have been used for the treatment of effluents containing heavy metals and residual oil, the adsorption process using natural adsorbents is a very encouraging method for pollutant removal [11]. A continuous adsorption process is very applicable to the batch adsorption process because a continuous process is cost-effective, feasible, requires less amount of adsorbent, and can be controlled [12]. Limited studies have been conducted on the treatment of POME using natural materials as adsorbents by a continuous adsorption process.

In this study, a novel type of adsorbent was prepared. It is known as alginate-mangrove composite beads coated with chitosan (AMCBCC). The adsorbent is in the shape of beads, which is the best form of biopolymer adsorbent for the removal of pollutants in wastewater, and also to prevent column clogging problems [13]. In addition, it is easy to separate the beads from the wastewater after treatment and they can also be easily regenerated. Mangrove bark is obtained from charcoal factories, alginate is a biopolymer obtained from the cell walls of brown algae, and chitosan is a copolymer obtained from chitin, which is produced from arthropods. These materials are natural and contain effective functional groups such as carboxylic, phenolic, and hydroxyl in mangrove bark, carboxylate and hydroxyl in alginate, and hydroxyl and amino in chitosan [14-16]. These functional groups are well known of their ability to remove pollutants from industrial wastewater [17].

The main purpose of the present research was to remove heavy metals and residual oil from actual POME using a new type of adsorbent (AMCBCC) by continuous adsorption studies in a fixed bed column under different bed height. Moreover, two kinetic models Thomas and Yoon-Nelson were also conducted in this work. 


\section{MATERIALS AND METHODS}

\subsection{Materials}

A sample of POME was collected from a palm oil mill in Seri Ulu Langat, Malaysia. The sample was left to cool and kept in a cooling room at about $4{ }^{\circ} \mathrm{C}$. The characteristics of the sample are specified in Table 1.

Mangrove bark was obtained from a charcoal factory in Kuala Sepetang, Perak, Malaysia, and chitosan with a medium molecular weight was obtained from a local factory in Malaysia. The other chemicals (sodium alginate $~ 98.5 \%$, acetic acid $99.8 \%$, nitric acid $65 \%$, calcium chloride $99.5 \%$, hydrochloric acid 37\%, sodium hydroxide $99 \%$, and sulphuric acid $\sim 95 \%$ ) were purchased from R\&M Chemicals. Hexane was supplied from H\&M Chemicals, and sodium sulfate anhydrous $~ 99 \%$ was supplied from Bendosen Chemicals.

Table 1: Characteristics of raw POME sample

\begin{tabular}{cc}
\hline Characteristics & Values \\
\hline Oil and grease & $10843 \mathrm{mg} / \mathrm{l}$ \\
COD & $42240 \mathrm{mg} / \mathrm{l}$ \\
Fe & $103.3 \mathrm{mg} / 1$ \\
Zn & $7.5 \mathrm{mg} / 1$ \\
pH & 4.9 \\
\hline
\end{tabular}

\subsection{Preparation of the Adsorbent}

The mangrove bark was washed with distilled water, dried at room temperature, ground, and sieved using a 250 -mesh sieve. It was then treated by $0.1 \mathrm{M} \mathrm{NaOH}$ for 2 hours, as $\mathrm{NaOH}$ is the best agent for improving the bark by increasing the active sites to obtain the maximum adsorption capacity [18]. Moreover, this modification was conducted to increase the hydrophobicity of the mangrove bark to adsorb residual oil [11-19]. Next, the bark was washed many times with distilled water until the $\mathrm{pH}$ of the solution became neutral. After that, the bark was filtered and dried in an oven at $60-63^{\circ} \mathrm{C}$ for $24 \mathrm{hrs}$. The treated bark was kept in a glass container for later use.

The mixture of alginate and mangrove bark (AM) was prepared by adding $5 \mathrm{~g}$ of sodium alginate into $200 \mathrm{ml}$ of distilled water. The mixture was then stirred continuously until the alginate had completely dissolved. Next, $2.5 \mathrm{~g}$ of the treated mangrove bark was added to the sodium alginate solution and mixed together until they became homogenous. A syringe pump device was used to form the alginate-mangrove composite beads (AMCB) by dropping the alginate-mangrove mixture into a solution of $0.2 \mathrm{M} \mathrm{CaCl}_{2}$. The beads were kept in the solution for $24 \mathrm{hrs}$ before being washed with distilled water to remove the excess $\mathrm{CaCl}_{2}$. They were then left to dry at room temperature and kept in a glass container for later use.

To coat the beads, a chitosan solution was prepared by adding $7.5 \mathrm{~g}$ of chitosan powder to $250 \mathrm{ml}$ of $0.2 \%$ acetic acid solution. The mixture was stirred continuously for $3 \mathrm{hrs}$ at 45 $50^{\circ} \mathrm{C}$ to obtain a viscous gel [20], Then, the chitosan solution was inserted into an ultrasonic device for 10 mins, after which, the solution was left at room temperature for $24 \mathrm{hrs} .40 \mathrm{~g}$ 
of AMCB was immersed in $250 \mathrm{ml}$ of chitosan solution and then stirred slowly at $45-50{ }^{\circ} \mathrm{C}$ for one hour. Next, the beads were removed from the chitosan solution and were immersed in $250 \mathrm{ml}$ of $0.1 \mathrm{M} \mathrm{NaOH}$ for one hour to neutralise the excess acetic acid [20]. Finally, AMCBCC was washed with distilled water until the $\mathrm{pH}$ of the solution became neutral. It was then left to dry at room temperature and kept in a glass container for further experimentation.

\subsection{Characterization Studies}

Fourier transform infrared spectroscopy (FTIR) was used to determine the surface functional groups in the AMCBCC, where the spectra were measured from 4000 to $600 \mathrm{~cm}^{-}$ ${ }^{1}$. The physical characteristics were checked for the beads to determine the weight and size of each bead.

\subsection{Column Adsorption Studies}

Continuous studies for the removal of heavy metals and residual oil from POME were performed in a fixed bed column packed with AMCBCC (Fig. 1). The glass column was 40 $\mathrm{cm}$ long and $1.9 \mathrm{~cm}$ in diameter.

The continuous studies were performed by studying the effects of bed height $(9,18$, and $27 \mathrm{~cm}$ ) at a constant $\mathrm{pH}$ obtained from the batch studies and at a constant flow rate of 3 $\mathrm{ml} / \mathrm{min}$, which was the lowest flow rate of this device. Based on the previous studies, it was revealed that at the minimum flow rate, a shorter breakthrough curve can be found [12, 2122]. In order to do the experiment, the POME was acidified to $\mathrm{pH} 3$ and put in the storage tank. The column was packed with AMCBCC until it reached the required height, and then the flow rate was set $3 \mathrm{ml} / \mathrm{min}$. The adjusted POME was then pumped through the fixed bed of AMCBCC. At regular intervals, the sample of treated POME was collected and prepared to be analyzed to determine the heavy metals and residual oil. The experiments were performed for about $540 \mathrm{~min}$.

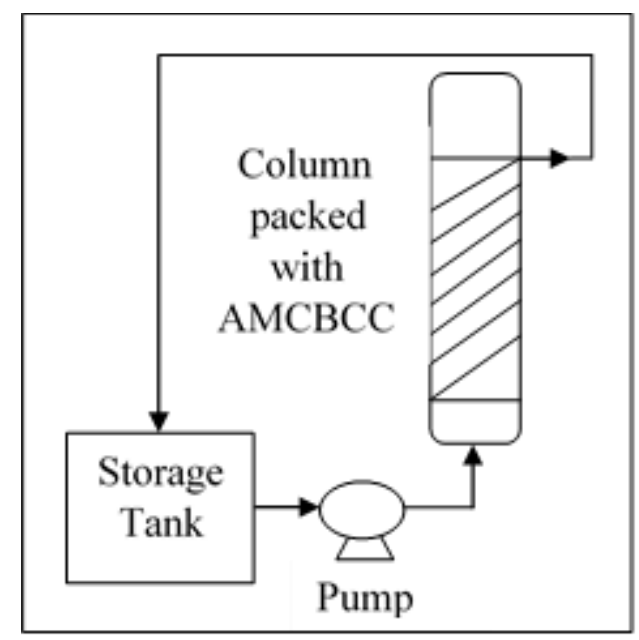

Fig. 1 Schematic diagram of adsorption column.

\subsection{Analytical Techniques}

\subsubsection{Determination of Heavy Metals}

The metals concentration in POME before and after treatment were determined using an inductively coupled plasma optical emission spectrometer (ICP-OES). In order to 
execute the test, the samples were filtered using filter paper and acidified by adding concentrated amount of $\mathrm{HNO}_{3}$ to prevent the precipitation of heavy metals [13]

\subsubsection{Determination of Residual Oil}

The amount of residual oil in POME before and after the treatment was determined using the Partition-Gravimetric method, a standard recommended method for the examination of water and wastewater [23]. In this method, the sample of POME was first acidified with 1:1 $\mathrm{H}_{2} \mathrm{SO}_{4}$ until the $\mathrm{pH}$ of the sample was equal or less than 2 . The acidified sample was transferred to a separatory funnel, and $30 \mathrm{ml}$ of hexane was added to the sample in the separatory funnel. The separatory funnel was capped and shaken 60 times for about 2 minutes while releasing the pressure from time to time. The layer was left to separate for 515 minutes. The lower layer was discarded. Then, the top layer was drained slowly into filter paper containing $1 \mathrm{~g}$ of anhydrous sodium sulphate placed in a funnel into a pre-weighted conical flask. The conical flask with the collected sample was then put in an oven at $70{ }^{\circ} \mathrm{C}$ until it was completely dried. The conical flask was cooled in a desiccator for 30 minutes and weighted. The residual oil concentration was calculated using equation (1):

$$
\text { Residual Oil }(\mathrm{mg} / \mathrm{L})=\frac{(W 2-W 1)}{\mathrm{V}} \times 10^{6}
$$

Where: $W_{1}$ and $W_{2}$ are the initial and final weight of the conical flask, respectively $(\mathrm{g})$, and $v$ is the volume of the sample $(\mathrm{ml})$.

\subsection{Mathematical Equation of the Fixed Bed Column in Continuous Studies}

The most important factor in the fixed bed column is the breakthrough curve, which is usually obtained from plotting a curve between $\left[\frac{C t}{C i}\right]$ versus the contact time $(\mathrm{t})$, where $C i$ and $C t$ are the inlet and outlet adsorbate concentration ( $\mathrm{mg} / \mathrm{l})$ [12]. The total adsorbed adsorbate in the column $\left(q_{\text {total }}\right)$ is determined using equation (2):

$$
q_{\text {total }}(m g)=\frac{Q A}{1000}
$$

Where: $q_{\text {total }}$ is the total metal ions or residue oil adsorbed quantity $(\mathrm{mg}) . Q$ is the volumetric flow rate $(\mathrm{ml} / \mathrm{min})$, and $A$ is the area under the curve which is determined from plot of the adsorbed concentration $\left(C_{a d}\right)$ versus time $(t)$.

$$
A=\int_{t=t \text { initial }}^{t=t \text { total }} \text { Cad } d t
$$

Where: $C_{a d}$ is the adsorbed concentration $(\mathrm{mg} / \mathrm{l})$ obtained from $\left(C_{i}-C_{t}\right)$.

The equilibrium adsorbate uptake $\left(q_{\text {e.exp }}\right)$ is calculated using equation (3):

$$
q_{\text {e.exp }}(\mathrm{mg} / \mathrm{g})=\frac{q \text { total }}{\mathrm{X}}
$$

Where: $X$ is the total dry weight of absorbent (AMCBCC) in column (g)

The total amount of metal ions or oil sent to the column $\left(M_{\text {total }}\right)$ is evaluated using equation (4):

$$
M_{\text {total }}(\mathrm{mg})=\frac{C i Q \text { t total }}{1000}
$$

The unadsorbed concentration at equilibrium of metal ions or oil $\left(C_{e q}\right)$ is obtained by equation (5):

$$
C_{e q}=\frac{\text { Mtotal }-q \text { total }}{V \text { eff }} \times 1000
$$


Where: $V_{\text {eff }}$ is the volume of effluent $(\mathrm{ml})=Q \times t_{\text {total }}$

The total removal percentage of metal ions or oil $(Y)$ is the ratio of the total capacity $\left(q_{\text {total }}\right)$ to the total amount of metal ions and oil sent to the column $\left(M_{\text {total }}\right)$ can be obtained from equation (6):

$$
Y=\frac{q \text { total }}{\text { Mtotal }} \times 100
$$

\subsection{Modeling of the Fixed Bed Column}

In this research, the description of the breakthrough behavior of iron ions, zinc ions and residual oil on the AMCBCC and the characteristic parameters $K_{T h}, q_{x}, K_{Y N}$, and $T$ were determined by two well-known models: the Thomas model and the Yoon-Nelson model.

\subsubsection{Thomas Model}

The Thomas model is designed to determine the maximum capacity of adsorption, which is one of the most important factors for column design. This model is also used in the description of the breakthrough curve of the column [12-21]. The linearized form of the Thomas equation is illustrated in equation (7):

$$
\ln \left[\frac{C i}{C t}-1\right]=\frac{K T h q x m}{Q}-K_{T h} C_{i} t
$$

Where: $C_{i}$ and $C_{t}$ are the inlet and outlet adsorbate concentration respectively ( $\left.\mathrm{mg} / \mathrm{l}\right), Q$ is the volumetric flow rate $(\mathrm{ml} / \mathrm{min}), t$ is the contact time $(\mathrm{min}), m$ is the mass of adsorbent $(\mathrm{g}), k_{T h}$ is Thomas kinetic coefficient ( $\left.\mathrm{ml} / \mathrm{min} . \mathrm{mg}\right), q_{x}$ is the maximum adsorption capacity $(\mathrm{mg} / \mathrm{g})$. With plot $\ln \left[\frac{C i}{C t}-1\right]$ versus $t$ from the slope and the intercept, values of $K_{T h}$ and $q_{x}$ are determined.

\subsubsection{Yoon-Nelson Model}

This model is developed based on the assumption of adsorption and breakthrough of adsorbate probability [12]. It is less complicated and needs fewer parameters than the other models; moreover, it is usually used to determine the time required for $50 \%$ of the adsorbate breakthrough $(T)$. The linearized form of Yoon-Nelson equation is illustrated in equation (8):

$$
\ln \frac{C t}{C i-C t}=K_{Y N} t-K_{Y N} G
$$

Where: $K_{Y N}$ is the Yoon-Nelson rate of constant $\min ^{-1}, T$ is the time required for $50 \%$ of adsorbate breakthrough min, and $t$ is the contact time min. Plot $\ln \frac{\mathrm{Ct}}{\mathrm{Ci}-\mathrm{Ct}}$ versus $t$ is to determine the slope and the intercept, and from the slope and the intercept, the values of $K_{Y N}$ and $T$ are calculated.

\section{RESULTS AND DISCUSSION}

\subsection{Characterization of AMCBCC}

From Fig. 2, it can be seen that the main peak was at the wave number of $3395.96 \mathrm{~cm}^{-}$ ${ }^{1}$, which refers to a hydroxyl group. This group was present in the mangrove bark, alginate, and chitosan [16, 24-25]. The wave number $1642.59 \mathrm{~cm}^{-1}$ refers to a carboxyl group, which was present in the alginate [26]. Moreover, the wave numbers 1034.87 and $779.23 \mathrm{~cm}^{-1}$ 
indicate the amine functional group, which can be considered as evidence of the coating by chitosan [27]. The physical characteristics of one bead are $0.0715 \mathrm{~g}$ weight, and $2.89 \mathrm{~mm}$ diameter. Figure 3 shows image of the AMCBCC bead.

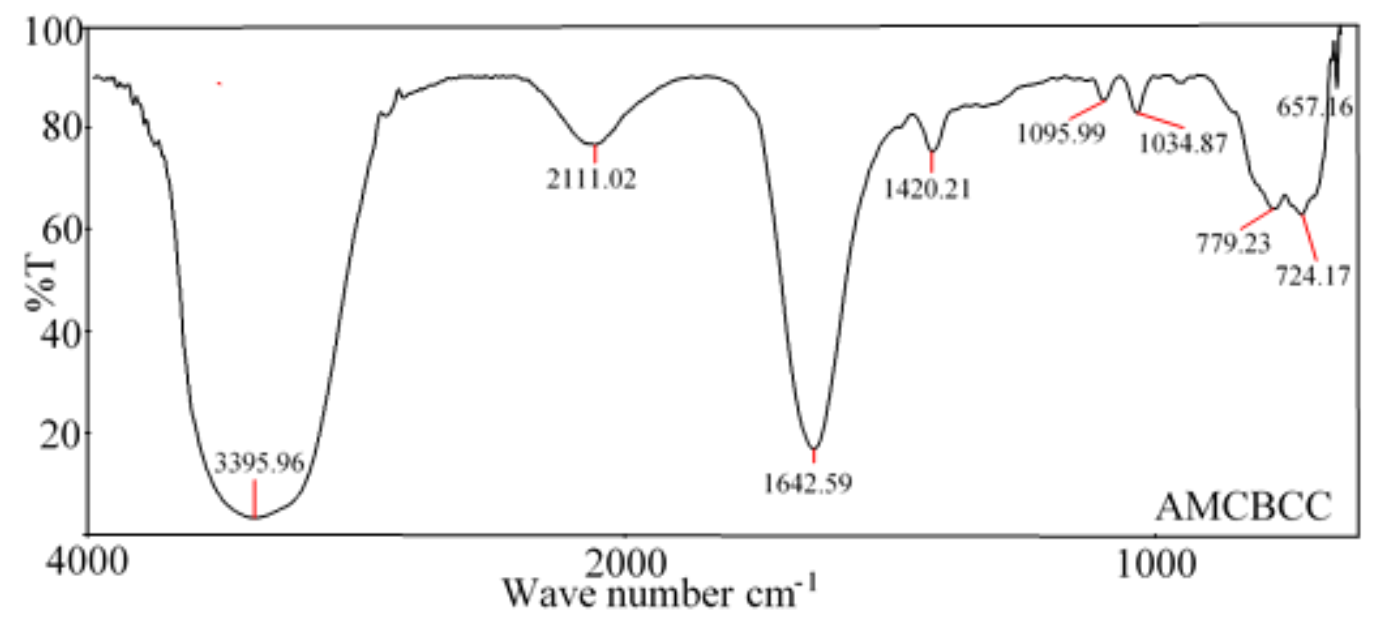

Fig. 2: FTIR spectrum of AMCBCC.

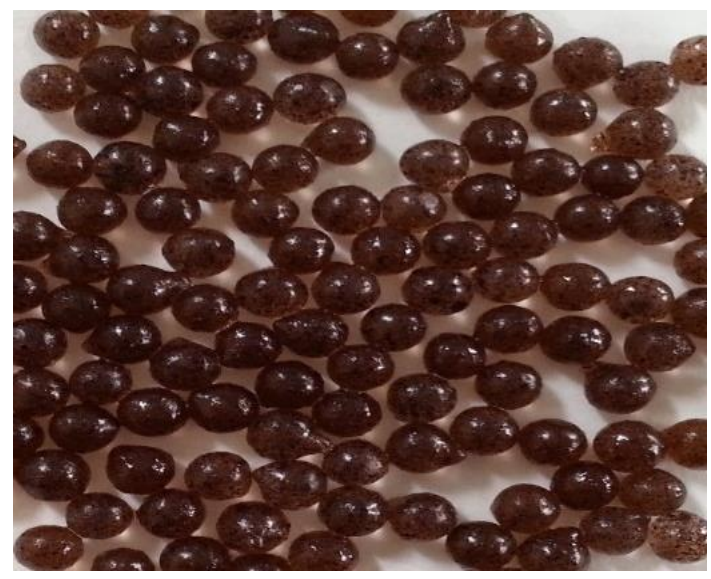

Fig. 3: Image of AMCBCC.

\subsection{Effects of the Bed Height}

The breakthrough curve of iron ions, zinc ions, and residual oil at different bed height are illustrated in Figs. 4, 5, and 6 respectively.

It is shown in Figs. 4, 5, and 6 that by increasing the bed heights from $9 \mathrm{~cm}$ to $27 \mathrm{~cm}$, a slower breakthrough curve occurred and the adsorbent (AMCBCC) needed a longer time to reach the exhaustion point (which was the point where the outlet concentration was equal to the inlet concentration). The explanation for this can be that increasing the adsorbent led to more available binding sites, more contact time, and more surface area [28]. On the contrary, decreasing the bed height led to a faster breakthrough curve and less time to reach the exhaustion point, and this trend had been reported in other research [29]. The mathematical characterization of the column parameters for iron ions, zinc ions, and residual oil can be seen in Table 2. 


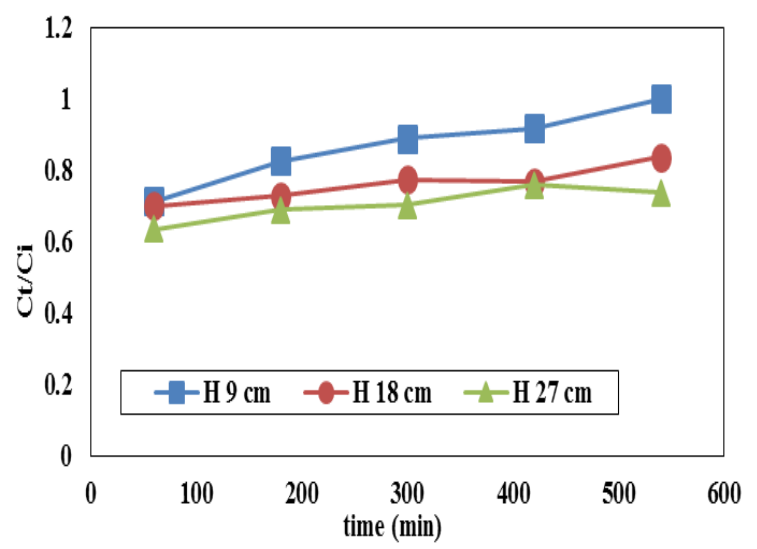

Fig. 4: Effect of the height on the adsorption of iron ions.

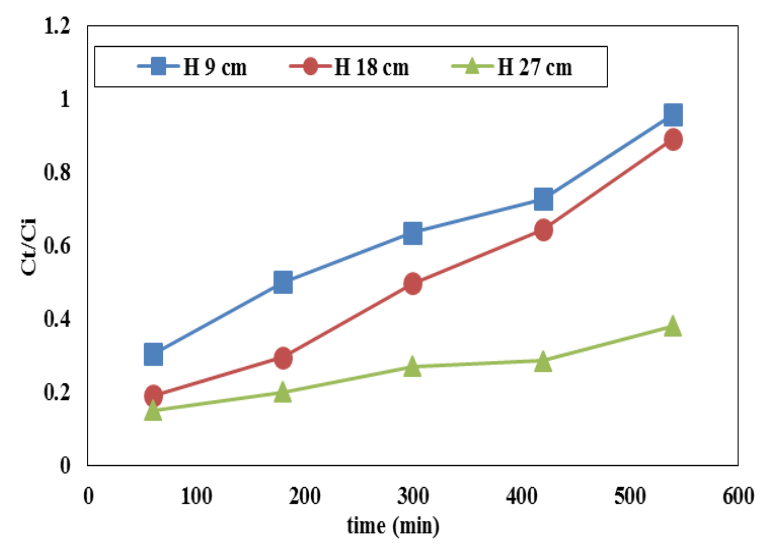

Fig. 5: Effect of the height on the adsorption of zinc ions.

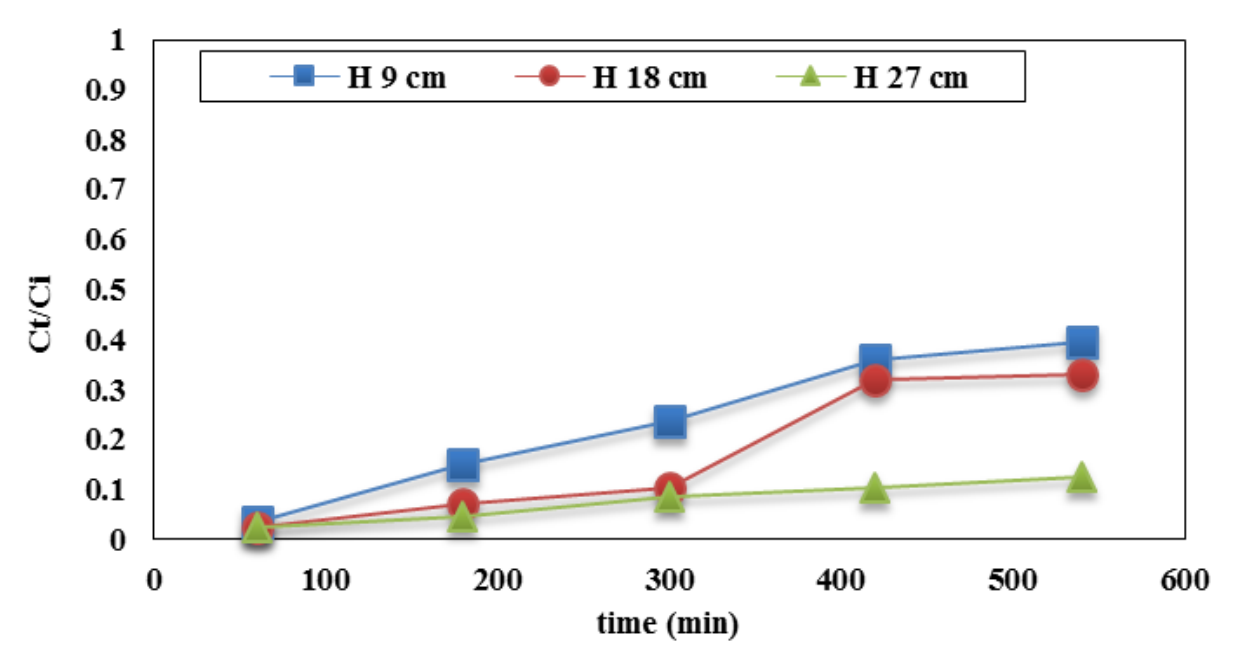

Fig. 6: Effect of the height on the adsorption of residual oil.

Table 2: Mathematical characterization of column parameters of iron ions, zinc ions, and residual oil at constant flow rate $Q(3 \mathrm{ml} / \mathrm{min})$

\begin{tabular}{|c|c|c|c|c|c|c|}
\hline Adsorbate & $\begin{array}{c}\begin{array}{c}\text { Bead } \\
\text { height } \\
(\mathrm{cm})\end{array} \\
\end{array}$ & $q_{\text {total }}(\mathbf{m g})$ & $M_{\text {total }}(\mathrm{mg})$ & $Y \%$ & $\begin{array}{c}q_{\text {e.exp }} \\
(\mathrm{mg} / \mathrm{g})\end{array}$ & $C_{e q}(\mathrm{mg} / \mathrm{l})$ \\
\hline \multirow{3}{*}{$\begin{array}{c}\mathrm{Fe} \\
\mathrm{Ci}(103.3) \\
\mathrm{mg} / \mathrm{l}\end{array}$} & 9 & 17.09 & 167.30 & 10.20 & 0.95 & 92.72 \\
\hline & 18 & 27.87 & 167.30 & 16.65 & 0.77 & 86.07 \\
\hline & 27 & 44.75 & 167.30 & 26.75 & 0.83 & 75.66 \\
\hline \multirow{3}{*}{$\begin{array}{c}\mathrm{Zn} \\
C i(7.5) \\
\mathrm{mg} / \mathrm{l}\end{array}$} & 9 & 4.33 & 12.15 & 35.60 & 0.24 & 4.80 \\
\hline & 18 & 5.55 & 12.15 & 45.67 & 0.15 & 4.07 \\
\hline & 27 & 9.32 & 12.15 & 76.74 & 0.17 & 1.74 \\
\hline \multirow{3}{*}{$\begin{array}{c}\text { Residual oil } \\
\mathrm{Ci}(\mathbf{1 0 8 4 . 3}) \\
\mathrm{mg} / \mathrm{l}\end{array}$} & 9 & 1366.45 & 1756.57 & 77.78 & 75.90 & 240.80 \\
\hline & 18 & 1408.65 & 1756.57 & 80.20 & 39.13 & 214.76 \\
\hline & 27 & 1458.49 & 1756.57 & 83.00 & 27.00 & 183.99 \\
\hline
\end{tabular}


It can be noticed from Table 2 that by increasing the bed height from 9 to $27 \mathrm{~cm}$, the total removal percentage $(Y \%)$ increased from (10.20 to 26.75) \% of iron ions, (35.60 to $76.74) \%$ of zinc ions, and from (77.78 to 83.00$) \%$ of residual oil. On the other hand, by increasing the bed height, the unadsorbed equilibrium concentration of iron ions, zinc ions and residual oil decreased from (92.72 to 75.66$) \mathrm{mg} / \mathrm{l}$, (4.80 to 1.74 ) $\mathrm{mg} / \mathrm{l}$, and (240.80 to $183.99) \mathrm{mg} / \mathrm{l}$ respectively. Similar results were reported by a previous study [12].

\subsection{Modeling of the Fixed Bed Column}

\subsubsection{Thomas Model}

To obtain the parameters in the Thomas model, a plot of $\ln \left[\frac{C i}{C t}-1\right]$ versus time is illustrated in Figs. 7, 8, and 9 for iron ions, zinc ions, and residual oil respectively at different bed height, where the slope and the intercept of the linear equation were used to calculate the $K_{T h}$ and $q_{x}$ respectively, which are presented in Table 3 . This model was applied to the range of $0.08<\frac{C t}{C i}<0.97$.

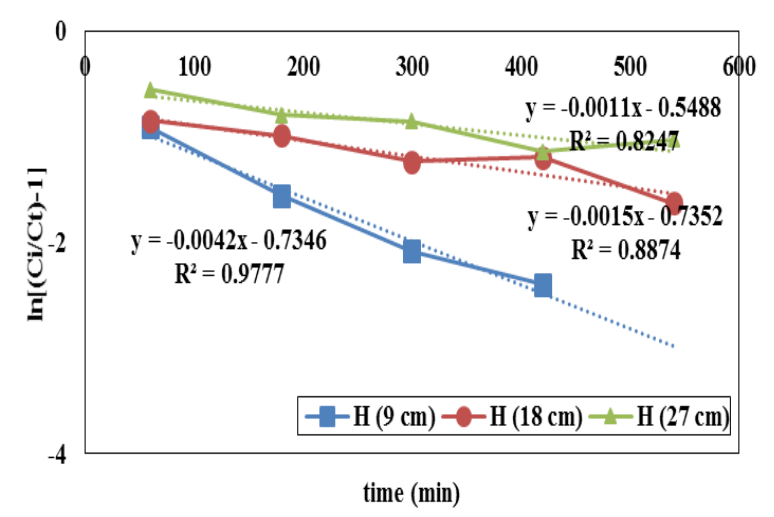

Fig. 7: Thomas model of iron ions at different bed heights.

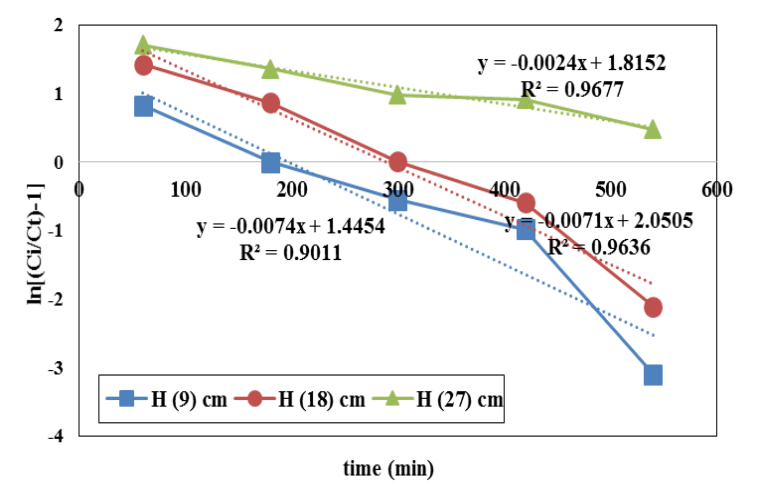

Fig. 8: Thomas model of zinc ions at different bed heights.

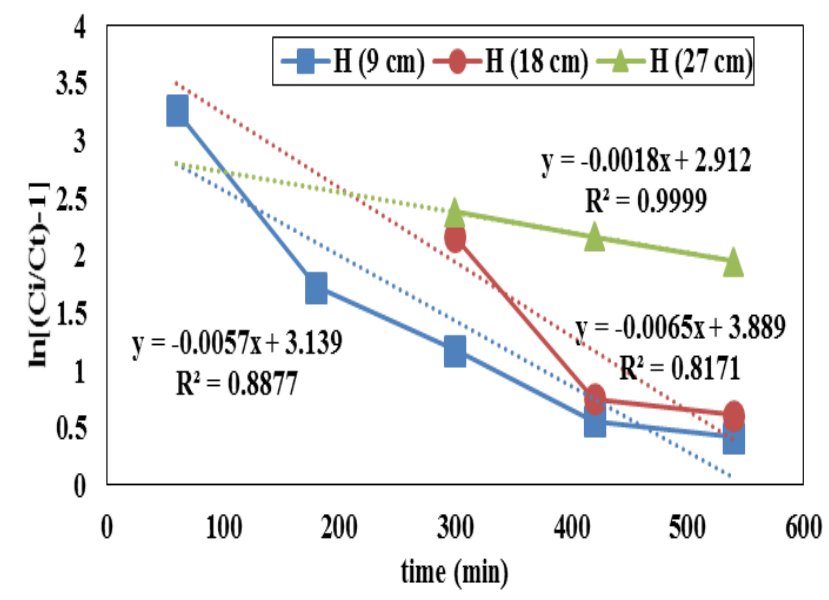

Fig. 9: Thomas model of residual oil at different bed heights.

It is shown in Table 3 that when the bed height was increased, the Thomas kinetic coefficient $\left(K_{T h}\right)$ decreased, and this was a normal trend, as mentioned in a previous research [30]. 
Table 3: Mathematical characterization of Thomas model of iron ions, zinc ions and residual oil at constant flow rate $Q(3 \mathrm{ml} / \mathrm{min})$

\begin{tabular}{cccccc}
\hline Adsorbate & $\mathbf{m}(\mathbf{g})$ & $\boldsymbol{K}_{T h}(\mathbf{m l} / \mathbf{m i n} . \mathbf{m g})$ & $\boldsymbol{q}_{\boldsymbol{x}}(\mathbf{m g} / \mathbf{g})$ & $\boldsymbol{q}_{\text {e.exp }}(\mathbf{m g} / \mathbf{g})$ & $\mathbf{R}^{\mathbf{2}}$ \\
\hline $\mathbf{F e}$ & 18 & 0.040 & 3.06 & 0.95 & 0.9777 \\
$\boldsymbol{C i} \mathbf{( 1 0 3 . 3 )}$ & 36 & 0.015 & 4.20 & 0.77 & 0.8874 \\
$\mathbf{~ m g / l}$ & 54 & 0.011 & 2.86 & 0.83 & 0.8247 \\
\hline $\mathbf{Z n}$ & 18 & 0.98 & 0.25 & 0.24 & 0.9011 \\
$\boldsymbol{C i} \mathbf{( 7 . 5 )}$ & 36 & 0.94 & 0.18 & 0.15 & 0.9636 \\
$\mathbf{~ m g / l}$ & 54 & 0.32 & 0.32 & 0.17 & 0.9677 \\
\hline Oil \& Grease & 18 & $5.26 \times 10^{-3}$ & 99.52 & 75.90 & 0.8877 \\
$\boldsymbol{C i} \mathbf{( 1 0 8 4 . 3 )}$ & 36 & $5.99 \times 10^{-3}$ & 54.15 & 39.13 & 0.8171 \\
$\mathbf{~ m g / l}$ & 54 & $1.66 \times 10^{-3}$ & 97.40 & 27.00 & 0.999 \\
\hline
\end{tabular}

Figures 10, 11, and 12 illustrated that the Thomas model fitted better with zinc ions than with iron ions and residual oil, because the predicted values of zinc ions by the Thomas model were more agreeable with experimental values than for iron ions and residual oil. The values of $\mathrm{R}^{2}$ from Table 3 also showed that Thomas models fitted better with zinc ions. Lastly, in comparison between the experimental $q_{e . e x p}$ and the Thomas theoretical qx for iron ions and residue oil, it was clear that there was a prominent difference between them, and this was a normal trend that was mentioned in a previous research [31]. On the other hand the values of $q_{e . e x p}$ and $q_{x}$ were in greater agreement for zinc ions.

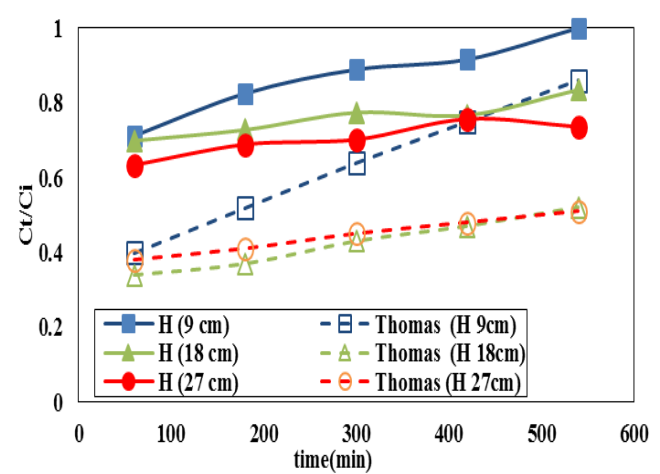

Fig. 10: Effect of bed height on iron ions removal predicted by Thomas model.

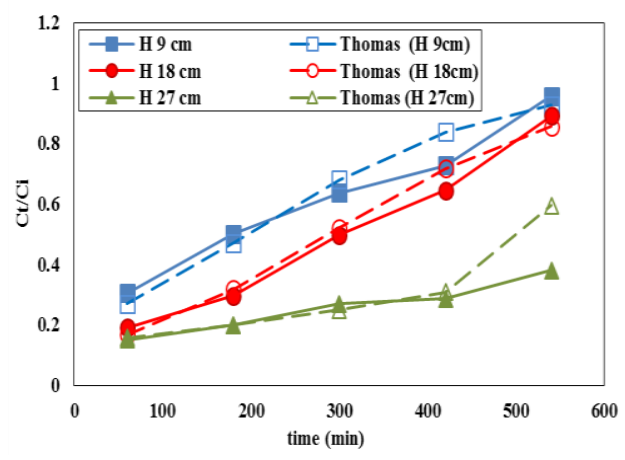

Fig. 11: Effect of bed height on zinc ions removal predicted by Thomas model.

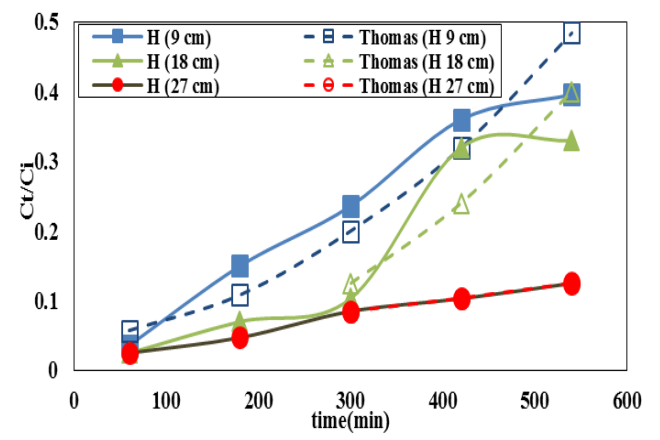

Fig. 12: Effect of bed height on residual oil removal predicted by Thomas model. 
It is illustrated by Table 4 that by increasing the bed heights from $9 \mathrm{~cm}$ to $27 \mathrm{~cm}$, the time required to reach 50\% adsorbate breakthrough $(T)$ increased from $174.92 \mathrm{~min}$ to 502.36 $\mathrm{min}, 196.60 \mathrm{~min}$ to $754.62 \mathrm{~min}$, and from $550.70 \mathrm{~min}$ to $1617.94 \mathrm{~min}$ for iron ions, zinc ions, and residual oil, respectively. This trend had been reported in a previous study [32].

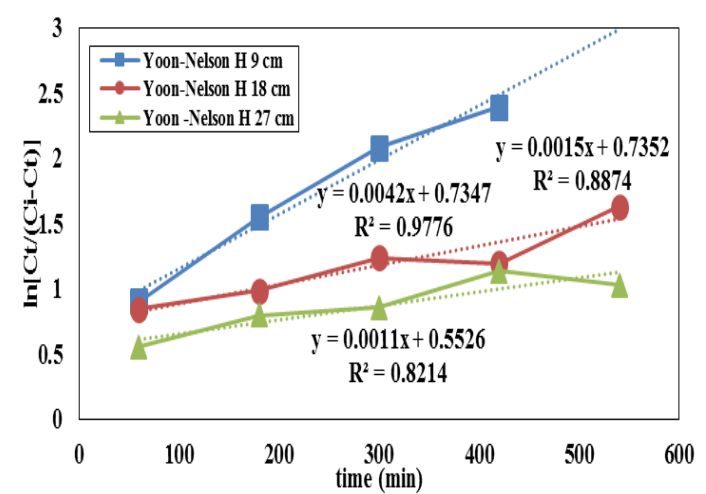

Fig. 13: Yoon-Nelson model of iron ions at different bed heights.

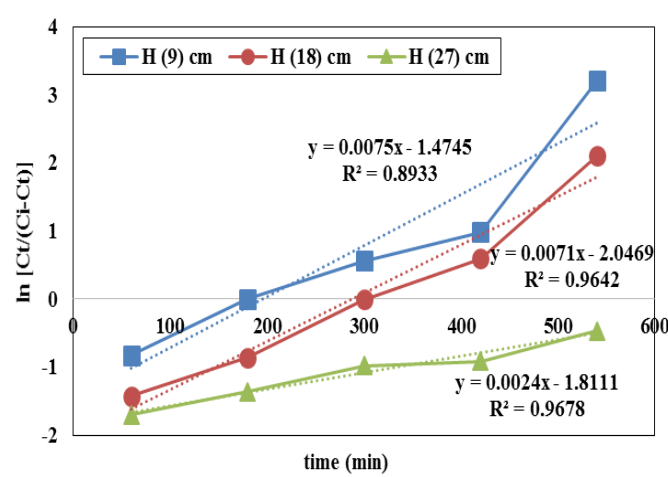

Fig. 14: Yoon-Nelson model of zinc ions at different bed heights.

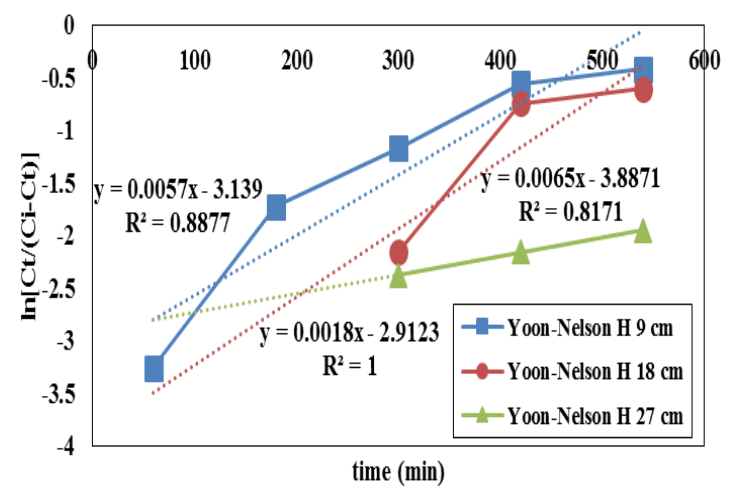

Fig. 15: Yoon-Nelson model of residual oil at different bed heights.

Table 4: Mathematical characterization of Yoon-Nelson of iron ions, zinc ions, and residue oil at constant flow rate $Q(3 \mathrm{ml} / \mathrm{min})$

\begin{tabular}{ccccc}
\hline Adsorbate & $\boldsymbol{H}(\mathbf{c m})$ & $\boldsymbol{K}_{Y N}(\mathbf{1} / \mathbf{m i n})$ & $\boldsymbol{T}(\mathbf{m i n})$ & $\mathbf{R}^{\mathbf{2}}$ \\
\hline $\mathbf{F e}$ & 9 & 0.0042 & 174.92 & 0.9776 \\
$\boldsymbol{C i} \mathbf{( 1 0 3 . 3 )}$ & 18 & 0.0015 & 488.33 & 0.8874 \\
$\mathbf{~ m g / l}$ & 27 & 0.0011 & 502.36 & 0.8214 \\
$\mathbf{Z n}$ & 9 & 0.0075 & 196.60 & 0.8933 \\
$\boldsymbol{C i} \mathbf{( 7 . 5 )}$ & 18 & 0.0071 & 288.29 & 0.9642 \\
$\mathbf{m g} / \mathbf{l}$ & 27 & 0.0024 & 754.62 & 0.9678 \\
& 9 & 0.0057 & 550.70 & 0.8877 \\
$\mathbf{R e s i d u a l ~ o i l ~}$ & 9 & 0.0065 & 598.01 & 0.8171 \\
$\boldsymbol{C i} \mathbf{( 1 0 8 4 . 3 )}$ & 18 & 0.0018 & 1617.94 & 1 \\
$\mathbf{m g} / \mathbf{l}$ & 27 & & &
\end{tabular}


Figures 16, 17, and 18 illustrated that the Yoon-Nelson model fitted better with zinc ions than with iron ions and residual oil because the predicted values by the Yoon-Nelson model of zinc ions were more agreeable with experimental values than for iron ions and residual oil. Moreover, the values of $\mathrm{R}^{2}$ from Table 4 also showed that the Yoon-Nelson model fitted better for zinc ions.

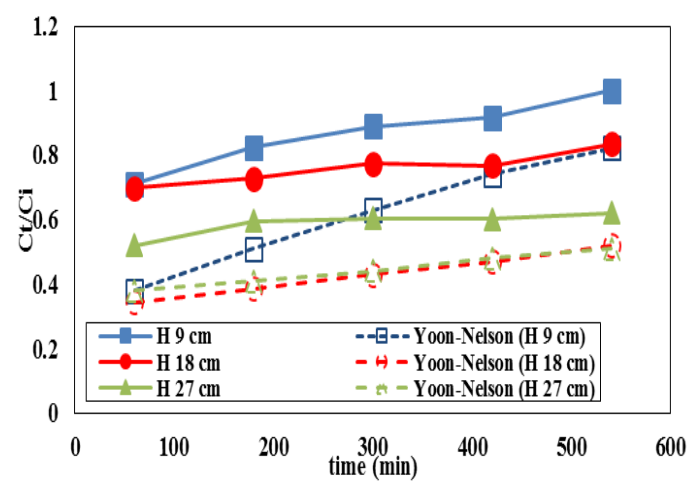

Fig. 16: Effect of bed height on iron ions removal predicted by YoonNelson model.

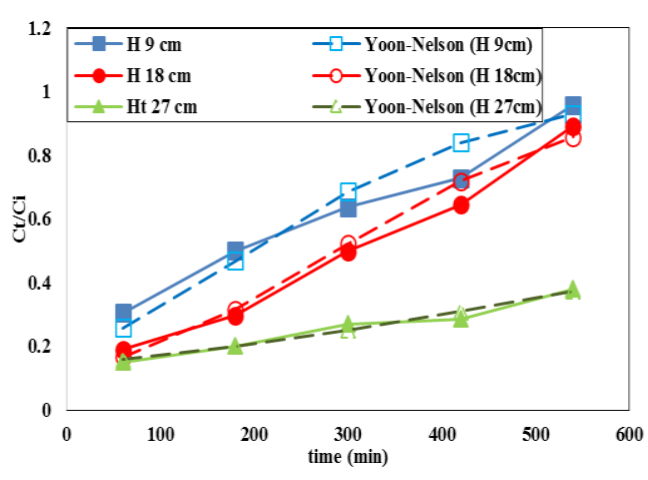

Fig. 17: Effect of bed height on zinc ions removal predicted by Yoon-Nelson model.

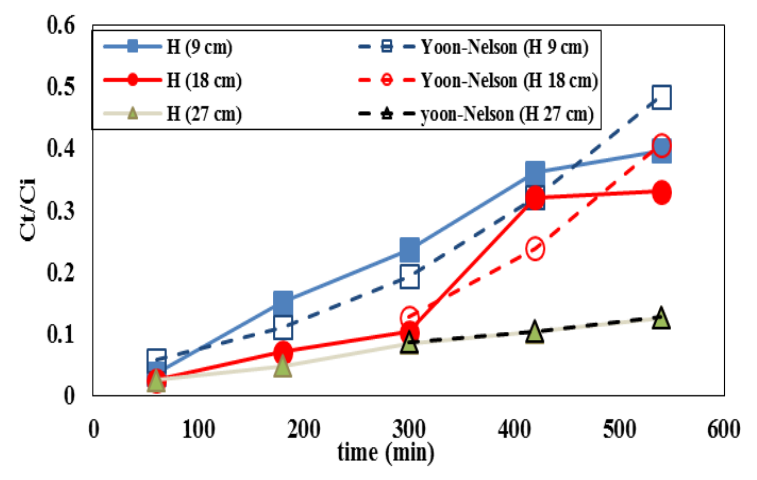

Fig. 18: Effect of bed height on residual oil removal predicted by Yoon-Nelson model.

\section{CONCLUSION}

In this work, the investigation of removal heavy metals and residual oil from POME was explored in a fixed bed column by a new type of adsorbent (AMCBCC). The adsorbent was characterized by FTIR to reveal the main functional groups in the beads. It was found that by increasing the bed heights from $9 \mathrm{~cm}$ to $27 \mathrm{~cm}$, the adsorbent (AMCBCC) needed a longer time to reach the exhausted point. Moreover, by increasing the bed height, the removal percentage for iron ions, zinc ions and residual oil increased from $10.20 \%$ to 26.75 $\%, 35.60 \%$ to $76.74 \%$, and $77.78 \%$ to $83.00 \%$, respectively. Furthermore, the Thomas model and the Yoon-Nelson model can both describe the adsorption of iron ions, zinc ions, and residual oil well, but the prediction data for both models are in greater agreement with the experimental data for zinc ions. Lastly, this research suggested that alginate-mangrove composite beads coated by chitosan (AMCBCC) are a promising adsorbent for the removal of heavy metals and residual oil from industrial wastewater. 


\section{ACKNOWLEDGMENT}

The authors are grateful to Universiti Putra Malaysia (UPM) for the financial support under grant (GP-IPS/2015/9453200).

\section{REFERENCES}

[1] Saeed MO, Azizli K, Isa MH, Bashir MJ. (2015) Application of CCD in RSM to obtain optimize treatment of POME using Fenton oxidation process. J. Water Process Engineering, 8:e7-e16.

[2] Chan YJ, Tan WJR, How BS, Lee JJ, Lau VY. (2015) Fuzzy optimisation approach on the treatment of palm oil mill effluent (POME) via up-flow anaerobic sludge blanket-hollow centered packed bed (UASB-HCPB) reactor. J. Water Process Engineering, 5:112-117.

[3] Azmi NS, Yunos KFM. (2014) Wastewater treatment of palm oil mill effluent (POME) by ultrafiltration membrane separation technique coupled with adsorption treatment as pretreatment. Agriculture and Agricultural Science Procedia, 2:257-264.

[4] Jameel AT, Muyubi SA, Karim MIA, Alam MZ. (2011) Removal of oil and grease as emerging pollutants of concern (EPC) in wastewater stream. IIUM Engineering Journal, 12(4):161-169.

[5] Bello M, Nourouzi M, Abdullah LC, Choong TS, Koay Y, Keshani S. (2013) POME is treated for removal of color from biologically treated POME in fixed bed column: applying wavelet neural network (WNN).Journal of hazardous materials, 262:106-113.

[6] Wu TY, Mohammad AW, Jahim JM, Anuar N. (2010) Pollution control technologies for the treatment of palm oil mill effluent (POME) through end-of-pipe processes.Journal of Environmental Management, 91(7):1467-1490.

[7] Bernard E, Jimoh A. (2013) Adsorption of $\mathrm{Pb}, \mathrm{Fe}, \mathrm{Cu}$ and $\mathrm{Zn}$ from industrial electroplating wastewater by orange peel activated carbon.International Journal of Engineering and Applied Sciences, 4(2):95-103.

[8] Ghaedi M, Mosallanejad N. (2013) Removal of heavy metal ions from polluted waters by using of low cost adsorbents: Review.Journal of Chemical Health Risks, 3(1):7-22.

[9] Ohimain E, Seiyaboh E, Izah S, Oghenegueke V, Perewarebo T. (2012) Some selected physico-chemical and heavy metal properties of palm oil mill effluents. Greener Journal of Physical Sciences, 2(4):131-137.

[10] Rupani PF, Singh RP, Ibrahim MH, Esa N. (2010) Review of current palm oil mill effluent (POME) treatment methods: vermicomposting as a sustainable practice. World Applied Sciences Journal, 11(1):70-81.

[11] Ahmad A, Bhatia S, Ibrahim N, Sumathi S. (2005) Adsorption of residual oil from palm oil mill effluent using rubber powder. Brazilian Journal of Chemical Engineering, 22(3):371-379.

[12] Lim AP, Aris AZ. (2014) Continuous fixed-bed column study and adsorption modeling: Removal of cadmium (II) and lead (II) ions in aqueous solution by dead calcareous skeletons. Biochemical Engineering Journal, 87:50-61.

[13] Zhang M, Zhang Y, Helleur R. (2015) Selective adsorption of $\mathrm{Ag}^{+}$by ion-imprinted Ocarboxymethyl chitosan beads grafted with thiourea-glutaraldehyde. Chemical Engineering Journal, 264:56-65.

[14] Rozaini C, Jain K, Oo C, Tan K, Tan L, Azraa A, Tong K. (2010) Optimization of nickel and copper ions removal by modified mangrove barks. Int J Chem Eng Appl, 1(1):84-89.

[15] Bée A, Talbot D, Abramson S, Dupuis V. (2011) Magnetic alginate beads for Pb (II) ions removal from wastewater. Journal of Colloid and Interface Science, 362(2):486-492.

[16] Igberase E, Osifo P, Ofomaja A. (2014) The adsorption of copper (II) ions by polyaniline graft chitosan beads from aqueous solution: Equilibrium, kinetic and desorption studies. Journal of Environmental Chemical Engineering, 2(1):362-369.

[17] Ahmad, Sumathi, Hameed. (2004) Chitosan: a natural biopolymer for the adsorption of residue oil from oily wastewater.Adsorption science \& technology, 22(1):75-88. 
[18] Argun ME, Dursun S.(2006) Removal of heavy metal ions using chemically modified adsorbents. J. Int. Environ. Appl. Sci, 1(1-2): 27-40.

[19] Asadpour R, Sapari NB, Isa MH, Orji KU. (2014) Investigation of Modified Mangrove Bark on the sorption of oil in water. Applied Mechanics \& Materials, 567:74-79.

[20] Popuri SR, Vijaya Y, Boddu VM, Abburi K. (2009) Adsorptive removal of copper and nickel ions from water using chitosan coated PVC beads. Bioresource technology, 100(1):194-199.

[21] Aksu Z, Gönen F. (2004) Biosorption of phenol by immobilized activated sludge in a continuous packed bed: prediction of breakthrough curves.Process biochemistry, 39(5):599613.

[22] Shavandi MA, Haddadian Z, Ismail MHS, Abdullah N. (2012) Continuous metal and residual oil removal from palm oil mill effluent using natural zeolite-packed column. Journal of the Taiwan Institute of Chemical Engineers, 43(6):934-941.

[23] Federation WE, Association APH. (2005) Standard methods for the examination of water and wastewater.American Public Health Association (APHA), Washington, DC, USA.

[24] Asadpour R, Sapari NB, Isa MH, Orji KU. (2014) Enhancing the hydrophobicity of mangrove bark by esterification for oil adsorption. Water Science \& Technology, 70(7):1220-1228.

[25] Kleinübing SJ, Da Silva FGC, Bertagnolli C, Da Silva MGC. (2011) Heavy metal sorption by calcium alginate beads from Sargassum filipendula. Chemical Engineering Transactions, 24:1201-1206.

[26] Li X, Kong X, Shi S, Zheng X, Guo G, Wei Y, Qian Z. (2008) Preparation of alginate coated chitosan microparticles for vaccine delivery. BMC biotechnology, 8(89): http://www.biomedcentral.com/1472-6750/8/89.

[27] Ahmad A, Sumathi S, Hameed B. (2005) Adsorption of residue oil from palm oil mill effluent using powder and flake chitosan: equilibrium and kinetic studies.Water research, 39(12):24832494.

[28] Sugashini S, Begum S, Meera K. (2012) Column adsorption studies for the removal of Cr (VI) ions by ethylamine modified chitosan carbonized rice husk composite beads with modelling and optimization. Journal of Chemistry, 2013: http://dx.doi.org/10.1155/2013/460971.

[29] Quek S, Al-Duri B. (2007) Application of film-pore diffusion model for the adsorption of metal ions on coir in a fixed-bed column. Chemical Engineering and Processing: Process Intensification, 46(5):477-485.

[30] Zhang J, Xu S, Zhang S, Du Z. (2008) Preparation and characterization of tamarind gum/sodium alginate composite gel beads. Iranian Polymer Journal, 17(12):899-906.

[31] Xu Z, Cai J-g, Pan B-c.(2013) Mathematically modeling fixed-bed adsorption in aqueous systems. Journal of Zhejiang University SCIENCE A, 14(3):155-176.

[32] Han R, Wang Y, Zhao X, Wang Y, Xie F, Cheng J, Tang M. (2009) Adsorption of methylene blue by phoenix tree leaf powder in a fixed-bed column: experiments and prediction of breakthrough curves. Desalination, 245(1):284-297. 